\title{
The Doctrine of Natural Justice under Civil and Military Administrations in Nigeria
}

\author{
D. O. Odeleye ${ }^{1}$ \\ ${ }^{1}$ Dean, Faculty of Law, University of Abuja, Nigeria \\ Correspondence: D. O. Odeleye, Dean, Faculty of Law, University of Abuja, Nigeria. Tel: 234-803-452-2672. \\ E-mail: odeleyedaniel@yahoo.com
}

Received: April 21, 2013 Accepted: May 2, 2013 Online Published: May 30, 2013

doi:10.5539/jpl.v6n2p231 URL: http://dx.doi.org/10.5539/jpl.v6n2p231

\begin{abstract}
In all human affairs, there has been established the need for a generally acceptable code of conduct and procedure in the administration of justice, civil or criminal which must be seriously observed by all in relationships with fellow human beings. This is particularly applicable to those who are saddled with the sacred responsibility of steering the ship of the State. In this wise, the place of natural justice is pivotal and has deservedly been elevated to the realm of great importance by all civilized communities. This article traces the origin of Natural Justice and discusses the two basic ideas in which Natural Justice is embodied i.e. audi alterem partem and nemo judex in causa sua. It also discusses the doctrine of Natural Justice under the Civil and Military rule in Nigeria and some other jurisdictions. The Article concluded by identifying some problems associated with the enforcement of Natural Justice and made recommendations.
\end{abstract}

Keyword: constitutional law, doctrine of natural justice

\section{Introduction}

Natural justice as a concept did not start with modern government; it is as old as the existence of mankind on earth evidently borne out of cultivated traditional attitudinal disposition of fairness in man to man relationship for which Natural Justice as a concept has attained notoriety. In fact, what seems to have happened to the doctrine in this age of globalization is the codification of several scattered principles of Natural Justice in statute books, partly for ease of reference and to concretize the long standing right of place of the doctrine.

\subsection{Origin of Natural Justice}

Historically, it was Hugo Grotius, a Dutch (born at Delft in Holland, 1583 - 1645), who built up what became known as the law of nature, or natural law. For his contribution to the growth of natural law, he is referred to as the father of the law of nature as well as the father of the law of nations (Note 1).

Before Grotius, opinion was generally prevalent that above the positive law, which is law which had developed by custom or by legislation of a State, there was in existence another law which has its root in human reason, and which could be regarded without any knowledge of positive law. This law of reason was called law of nature or natural law.

According to Dr. Ezejiofor (Note 2), the concept of natural law was first formulated systematically by the Stoics after the breakdown of the Greek City States; for the Stoics, natural law was universal as it applied not only to citizens of certain states, but rather to everybody everywhere in the cosmopolis. This law was superior to any positive law and embodied those elementary principles of justice apparent to the eye of reason. It is from this natural law that we derive fundamental rights or natural rights which may be defined as moral rights which every human being, everywhere at all times ought to have, simply because of the fact that, in contradiction with other beings, we are rational and moral. No one may be deprived of these rights without grave affront to justice (Note 3 ).

The rules of natural justice are therefore a part of natural law and relate to the minimum standards of fair decision-making imposed by the common law on persons and bodies that are under a duty to act judicially (Note 4). The principles of Natural Justices are embodied in two basic ideas, audi alterem partem and nemo judex in causa sua. 


\section{Audi Alterem Partem}

The principle of audi alterem partem (hear both sides) which is one of the twin pillars of natural justice is primarily about giving an individual the opportunity of being heard before he can incur either the loss of liberty, right or property for any wrong or offence committed by him. Most of the earliest reported decisions in which the rule was applied concerned summary proceedings before Judges. In R. v. Dyer (Note 5), the court held that the service of summons upon the party affected was a condition precedent to the validity of such proceedings not only in criminal matters but also in applications for the issue of distress, warrants and orders for levying taxes and other charges imposed by public authorities upon their subjects. This was also pointed out in Harper v. Carr (Note 6).

In the earliest time, the application of the rule was so strict that a Judge who adjudicated summarily without having issued a summons to the affected parties was at one time punishable in the court of the king's Bench for misdemeanor as was held in R. v. Venable (Note 7).

Basically the operation of the rule of audi alterem partem in the beginning could also be viewed from the perspective of deprivation of offices and other official appointments. An example was in 1615, when James Bagg, a Chief Burgess of Plymouth, who had been disenfranchised for singularly unbecoming conduct was reinstated by mandamus because he had been removed without a notice of hearing in the Bagg's Case (Note 8).

Also, in Caapel v. Child (Note 9), a Bishop who was empowered by statute to order a vicar to appoint a curate (to be paid by the vicar) when satisfied either of own knowledge or by affidavit, that the vicar had neglected his duties was said to be duty bound to give the vicar notice and opportunity to be heard before making the order.

Invariably, the scope of the application of audi alterem partem became broadened in the nineteenth century to embrace such areas as the conduct of arbitrators. In the case of Re-Brook (Note 10), to include professional bodies and voluntary association in the exercise of their disciplinary functions in the case of Debbis v. Llyod (Note 11) every tribunal or body of persons invested with authority to adjudicate upon matters involving civil consequences and finally to individuals in the case of Wood v. Wood (Note 12).

However, the best known statement of the doctrine of audi alterem partem in the administration of English law was formulated by the House of Lords exercising its appellate function of a government department in the case of Board of Education v. Rice (Note 13), where Lord Loreburn L.C. held as follows:

Comparatively recently, statutes have extended, if they have not originated, the practice of imposing upon departments of officers of state the duty of deciding or determining questions of various kind. In the present instance, as in many others, what comes for determination is sometimes a matter to be settled by discretion, involving no law. It will, I suppose, usually be of an administrative kind; but sometimes it will involve matter of law as well as matter of fact, or even depend upon matter of law alone. In such cases they must act in good faith and fairly listen to both sides for that is a duty lying upon everyone who decides anything. But I do not think they are bound to treat such a question as though, it were a trial ... they can obtain information in any way they think best always giving a fair opportunity to those who are part in the controversy for correcting any relevant statement prejudicial to their views.

Basically, a breach of this rule will, as we have seen rendered a decision of an inferior tribunal invalid if or when the matter is taken up to a high court (Note 14). Thus, in The Queen v. The Governor-in Council, Western Nigeria, Ex parte Adebo (Note 15), the High Court of Western Nigeria held that certiorari would lie to quash the order of the Government Council deposing the applicant as Olofin of Ilishan because the Chief was not given an adequate opportunity to prepare his defense against the charges against him. In his judgment, Charles J. stated that: (Note 16)

It is important to recognize that there is a presumption that when the legislature confers a power on an authority... it intends that the power shall be exercised judicially in accordance with the rule of natural justice, that the individual concerned must be given an adequate opportunity to be heard

In The Queen v. The Acting Provincial Secretary, Uyo, ex parte Imeh (Note 17), the High Court granted an order of certiorari to quash the conviction of the applicant who was convicted by a Native Court on a charge in which he was not given an adequate opportunity to plead or answer to the charge preferred against him.

Where the rule is infringed, the court will intervene. Thus, in The Queen v. The Resident, Ijebu Province, ex parte Oshunlaja (Note 18), where the Governor in council approved the appointment of a Chief, whose appointment was made without "due enquiry", Ademola, C. J. (as he then was) said: 
The court is precluded by law from interfering in the matter of selection of a Chief, it will therefore not interfere, but it will be standing between the executive and the members of the public, so far as the legislature on the point permits, and if something is being done which is contrary to natural justice, or certain things required by law are not done, it will interfere.

Nevertheless, in The Queen v. Governor - in- Council, Western Nigeria, Ex parte Odubote (Note 19), Fatayi Williams, J. (as he then was) in his judgment said:

It is my view, settled law that where a statute seeks to take away the jurisdiction of a Superior Court, that privative provision will not be effective where the inferior court or body exercising judicial or quasi-judicial function had acted in violation of the statute or has acted without jurisdiction

\subsection{Nemo Judex in Causa Sua}

This doctrine which literarily means don't be a judge in your own cause is otherwise known as the rule against bias, which of course is the second of the twin pillar of the principle of natural justice.

It is a rule, which is principally concerned with impartiality preventing an umpire from prejudging whoever is standing trial before any tribunal. The instances of bias may clearly arise in a number of ways, one of which is where the umpire has direct pecuniary interest in the subject matter before him in which case he ought to transfer the matter to an independent arbitrator as illustrated in the case of Dimes v. Grand Junction Canal (Note 20) which set aside the decision of the Lord Chancellor who was a shareholder in the company appearing before him.

Even where an umpire has no pecuniary interest in the matter being litigated before him, he may still be disqualified on the ground of bias. Thus, in R. v. Sussex Justices, Ex parte McCarthy (Note 21), a Solicitor was acting as clerk to the Justice in the hearing of a traffic offence, following a collision and his firm was due to act for the other party to the accident in civil proceedings. Although, the Solicitor's clerk was obviously passive in the course of hearing, a writ of certiorari to quash the conviction was granted. Lord Hewart, C.J. held that:

It is of fundamental importance that justice should not only be done, but should manifestly seen to be done

Equally, in Metropolitan Properties Co. FGC Ltd. v. Lannon (Note 22), the Chairman of a Rent Tribunal was also a Solicitor who had been involved in protracted disputes with the Landlords. His determination of the rent was quashed by certiorari since right minded persons might think that there was a real likelihood of bias. It is worthy to state here that the real essence of the rule against bias is to divest an individual of undue opportunity of assuming adjudicatory power or partake in the subject matter of which he is in any manner whatsoever connected with a view to engendering confidence of the affected parties in the verdict reached, since justice is rooted in confidence.

In fact, it can be stated here without any fear of contradiction that the concept of natural justice, the notion of law and justice are inextricably intertwined, as the observance of the one produces the other. This position was judicially supported by the Nigerian court in Adeboanu Manufacturing Industries (Nig.) Ltd. v. Akiyode, (Note 23) where the court held that:

Perhaps, the concept of natural justice is better explained in two Latin maxims viz: audi alterem partem and memo judex in causa sua. The first maxim simply translates into the golden rule that no one shall be condemned, punished or deprived of property in any judicial or quasi - judicial proceedings unless he has been heard or be seen to have been given an available opportunity to be heard. That has long been a received rule of the principles of natural justice. The second ... directs that no one shall be a judge in his own cause. These are the twin pillars on which the concept of natural justice rests. When it is being questioned whether justice has been done in any particular case, a safe ground for reason of difficulty of the terms is to assert that justice has been done according to law, for the law itself must of necessity include the procedure laid down for its attainment. To have the attainment of justice to a free for all pursuit and jettison the rule is to pave way for judicial high handedness and the omnipotence of individual judges.

From the former, it may not be too difficult to observe the relevance and/or co-existence of these two concepts.

Indeed, it is beyond dispute that the concept of natural justice is ageless and has traversed all known human generations with inexorable tenacity. It is a concept that has been much debated, analyzed and discussed in multitudinous details by various schools of thought. Yet, it ever remains magnetizing and inexhaustibly available for searchlight by legal researchers and the thrust of sagacious academic interest. 
Nevertheless, any meaningful consideration of the concept of natural justice would necessarily involve an appreciation of certain essential doctrines which are irrepressibly knitted for a fuller understanding of the concept itself.

Be that as it may, these rules of natural justice are so fundamental and necessary in the administration of judicial and quasi-judicial functions that a breach of any of them may lead to setting aside or quashing of the decision reached in such proceedings. At this junction, it is pertinent to point out that a decision reached in breach of any of the rules of natural justice renders it voidable and not void. (Note 24)

\section{Natural Justice in Civil and Military Administrations}

Civil Administration is synonymous with a democratic administration. Democracy which is the indispensable turn of the rule of law is based on two key elements to wit popular control over collective decision making and makers, and secondly equal right to share in such control, i.e. political equality (Note 25).

Thus, a civil administration will necessarily showcase a system of administration where constitutionalism reigns supreme which the observance of the principles of natural justice should form the bedrock. It is to be noted however, that this is in contrast with Military administrations which have attained unrivalled notoriety for a tradition of operating from the opposite role of constitutionalism or the rule of law. Understanding the Military attitude is tragically informed by the system of coup d'etat that customarily produces every Military administration.

The various coup d'état in the country and the long years of military rule has dishearteningly given way to the rule of force to a scandalous extent which has resultantly led to the rule of law being relegated to the background. For instance, the Military administrations under the rulership of leaders like Buhari/Idiagbon, Babangida and the late Sanni Abacha treated Nigerians to immeasurable brutalization of the citizens. They were either gamesomely killed or hurled into prison on one trumped up offence or the other without trial. This however, is not to say that civil administrations are diametrically exonerated from the violation of the principles of natural justice in the course of governance, as instances are not wanting where a democratic administration turns tyrant of a magnitude almost equal to that of Military administrations. They have to a lesser extent demonstrated flagrant disregard to the observance of the fundamental norms of a democratic administration which make the observance of the principles of natural justice possible.

Nevertheless, it is pertinent to state that different degrees and forms of violation of the principles of natural justice exist under the two systems of administration.

\subsection{Natural Justice in Civil Administration in Nigeria}

The constitution is today accepted as grundnorm upon which the existence of any democratic government is based, being the collective will of the people. The preamble to the 1999 Constitution (as amended) (Note 26) provides that:

\section{We the people of the Federal Republic of Nigeria having firmly and solemnly resolved to live in unity and harmony....... do hereby make, enact and give to ourselves this constitution.}

All the Nigerian Constitutions since independence have always stated very explicitly that the people are the makers of the constitution as a collective resolve. That being so the constitution which is a symbol of the will of the people is supreme. However, these claims as reflected in the preamble that the constitution is the collective will of the people may be a fallacy as the constitutions of Nigeria since independence were either a product of a colonial or a military parting gift to Nigerians.

In any event, constitutionalism of government which civil administration is noted for is certainly an indispensable factor for meaningful observance of the principles of natural justice. Constitutionalism in itself may simply be described as adherence to the due process or rule of law as opposed to arbitrariness, tyranny or dictatorship.

The present Nigerian Constitution being a Federal Constitution necessarily has the legislative, the executive and the judicial arms of government exclusive of each other. All these three fundamental arms of government are duty bound to uphold the provisions of the Nigerian constitution which among other things contains provisions on human rights of the citizens as revealed in its chapter IV. Interestingly enough, it is within the purview of Chapter IV of the 1999 Constitution that natural justice finds a firm expression as it affects fair hearing.

Section 36(1) of the 1999 Constitution (Note 27) provides:

In determination of his civil rights and obligations, including any question or determination by or against any government or authority, a person shall be entitled to a fair hearing within 
a reasonable time by a court or other tribunal established by law and constituted in such manner as to secure its independence and impartiality.

In Ika Local Government Area v. Mba (Note 28), the meaning of fair hearing under section 36 of the Constitution was stated as follows:

a trial or investigation conducted according to all legal rules formulated to ensure that justice is done to the parties to a cause or matter

The above definition of fair hearing was also referred to in Ezechukwu v. Onwuka (Note 29). However, in Fagbule v. Rodrigues (Note 30) and NEPA v. Arobieke (Note 31), it was stated that fair hearing involves a situation where having regard to all the circumstances of a case, the hearing may be said to have been conducted in such a manner that an impartial observer will conclude that the tribunal was fair to all the parties.

In any case, where the issue of fair hearing has been made an issue, the court must first of all determine it before all other issues in the matter. This was the position of the court in Babalola v. Oshogbo L. G. (Note 32).

Section 36(1)(a) of the 1999 Constitution makes provision for a person whose rights and obligations may be affected to be duly represented before reaching a decision affecting him. In Yakubu v. Chief of Naval Staff (Note 33), where the accused was denied bail and access to Counsel of his choice, it was held that it constituted a complete violation of his right to fair hearing.

Moreover, section 36(4) of the Constitution provided that when any person is charged with a criminal offence, he shall, unless the charge is withdrawn, be entitled to a fair hearing in public within a reasonable time by a court or tribunal.

Section 36(5) went on to provide that every person charged with a criminal offence shall be presumed to be innocent until he is proved guilty. Section 36(6)(a) states that every person charged with a criminal offence shall be entitled to be informed promptly in the language that he understands and in detail of the nature of the offence. In Unity Bank Plc. v. Bouari (Note 34), it was held that the fair hearing provision is an aggressive one, not a cowardly one.

Be that as it may, consideration of the principles of natural justice under a civil administration would necessarily involve an x-ray of the three arms of government from the view points of the principles of fair hearing.

\subsection{Natural Justice and the Legislature}

As earlier observed, an essential feature of a civil administration is the predominance of the rule of law. It is in furtherance of this principle that the doctrine of separation of powers has been regarded as complementary of the rule of law as each arms of government is assigned its distinct functions which should not be exceeded or compromised except as allowed by the constitution in specified circumstances. The Constitutions established a bi-cameral National Assembly as the Federal Legislature.

Essentially, the various Nigerian Constitutions have always made provision for the supremacy of the Constitution. Thus, if any other law is inconsistent with the provisions of the Constitution, then that other law shall to the extent of its inconsistency be void. The supremacy of the Nigerian Constitution was buttressed by the Supreme Court in INEC \& Anor v. Balarabe Musa \& Anor (Note 35) when it held per Ayoola E. O. that:

First, all powers, legislative, executive and judicial must ultimately be traced to the Constitution. Secondly, the legislative powers of the legislature cannot be exercised inconsistently with the Constitution, where it is so exercised; it is invalid to the extent of its inconsistency...

As a corollary to the foregoing in a democratic government, the judicial power is vested in the court. The supreme court of Nigeria confirmed this in Global Trans \& Anor v. Free Enterprises Nig (Note 36)., where it held:

There is no doubt however, that under our Constitution, the three arms of government in both the federal and the states are distinct and separate and each has its functions and powers clearly spelt out. The judicial powers of the federation and States are vested in the courts established for the federation and the State.

Flowing from the foregoing therefore is the fact that the legislature cannot validly make law that is in violation of the Constitution such as ousting the constitutionally conferred jurisdiction of the Courts (Note 37). The National Assembly possess necessary legislative competence to make laws for the country in respect of matters stipulated in the exclusive legislative list as well as the concurrent legislative list as set out in parts I and II of the second schedule to the 1999 constitution (Note 38). Whilst the state House of Assembly is vested with the state legislative 
power in respect of matters set out in the concurrent legislative list in part II of the second schedule of the constitution (Note 39). However, the legislative powers must be exercised in conformity with the constitutional provisions to be valid and operative. Thus, in A. G. 36 States v. A. G. Federation (Note 40), the Supreme Court held as incompetent for National Assembly to make laws extending or altering the tenure of elected officers to local government councils and or making laws with respect to division of a local government area into wards for the purpose of elections. The court declared null and void, the provisions of section 110 (1) and 112 of the Electoral Act 2001.

It is noteworthy that the 1999 Constitution has given local administration in Nigeria to the state governments and it is the state Houses of Assembly that has legislative competence over such an issue. Similarly, in A. G. Ondo State v. A. G. Federation \& Ors (Note 41), the Supreme Court declared certain provisions of the Anti-Corruption and other Related Offences Act (Note 42) unconstitutional. The court specifically frowned at the provisions of Section 26 (3) of the law which provides that:

"prosecution of an offender under the law shall be concluded and judgment delivered within ninety working days of its commencement, save that the jurisdiction of the court to continue to hear and determine the case shall not be affected where good ground exist for a delay".

The provision violates the principle of fair hearing and is therefore unconstitutional.

Generally, any legislative enactment, which violates the rights of the citizen, would be unconstitutional. For instance, all the rights enshrines in Chapter IV of the 1999 Constitution are constitutionally sacrosanct, any legislation which detracts, impairs or take any of them away except as permitted by the constitution itself will be against the spirit of the Constitution.

In any event, the entire legislative Houses in the Federation in a civil administration are inferior and subordinate to the Nigerian constitution. Thus, the entrenched clauses including the individual's fundamental human rights such as the right to fair hearing cannot be altered by legislative enactment except the very complicated process dictated by the constitution is religiously followed. In this way, it is made extremely difficult for any civilian administration to light heartedly abrogate the individual's right except in the case of national necessity such as during war or public emergency.

\subsection{Natural Justice and the Executive}

The Executive arm of the government is arguably the most essential arm of any civilian administration. This is because it has always existed whether the government is military or civil. It is an arm that is saddled with the responsibility of execution and maintenance of the constitution and laws validly made by the legislature.

The Executive arm of government is more prone to abuse and violation of principles of natural justice, basically it is the very arm of government that directly interacts with the populace in the course of execution of the law. One would expectedly therefore hope that this arm should be more cautious when it comes to the observance of the principles of natural justice in general.

Regrettably, however, the Nigerian experience has shown that both the principles of natural justice and the rule of law are more in breach than in observance as executive lawlessness has unfortunately become a recognized feature of Executive actions in Nigeria.

Instances of Executive lawlessness ranges from the disobedience to court orders, arbitrariness, usurpation of functions and powers of other arms of government to the encroachment of citizen's rights. The faceoff between the administration of President Olusegun Obasanjo and the Nigerian Labour Congress (NLC) over arbitrary increases in the pump price of petroleum is a demonstration of Executive lawlessness.

Disobedience to court's order by the Executive has had an adverse effect on the observance of the principles of natural justice in the country. Thus, even where a citizen whose rights have been infringes upon by the Executive action gets judgment in court, his victory may still be frustrated by non-compliance by the Executive. Thus, the situation is more pathetic when it is realized that it is the Executive arm of government that has the constitutional responsibility of enforcing the law while disobedience of courts' orders in a military administration through depreciable may be understandable, having in mind its genesis; same cannot be said of a civil administration which is founded on the rule of law.

In Minister of Internal Affairs v. Shugaba (Note 43), Executive lawlessness was exhibited when without a trial, let alone a fair hearing; Abdulrahman Shugaba was deported on the allegation of his not being a Nigerian, but an illegal immigrant. 
It however remains to mention here that Executive lawlessness hampers the observance of the principles of natural justice and thereby constitutes a big minus on civil administrations which one would have expected would be adherent to the rule of natural justice.

\subsection{Natural Justice and the Judiciary}

The judiciary is traditionally seen as the last hope of the common man; of course, it is a forum where remedies are obtainable against any oppressive act of the other two arms of government as well as individuals. Indeed, the judicial process is said to be integrative in nature, that is, it solidifies the multi-furious strands that holds society together.

It should be noted however that incidences of the Judiciary acceding to unnecessary adjournments delay court trials and this negates the principle of Natural Justice as Justice delayed is Justice denied. In a bid to curtail adjournments, the Bill for an Act to repeal the Criminal Procedure Act (Note 44), Criminal Procedure Code (Note 45), Administration of Justice Commission Act (Note 46) and enact the Administration of Criminal Justice Act applicable in Federal Courts and Courts of the Federal Capital Territory to make provision for speedy and efficient administration of Criminal Justice and provide for other matters related thereto 2013, has passed a second reading at the Nigerian House of Representatives. (Note 47)

Basically, the judicial power of the Nigerian Courts is contained in section 6 of the 1999 constitution. Thus an efficient and virile judiciary is Sine qua non to an independent judiciary. However, the judiciary in Nigeria cannot be regarded as fully independent due to a number of factors such as the mode of appointment of judges which is done by the Executive on the recommendation of the National Judicial Council, insecurity of tenures as the Executive may fire judges at will upon flimsy excuse or for no reason at all. For instance, in 1975, many judges including Justice Elias, the then Chief Justice of Nigeria were removed from office without the observance of the elementary rules of natural justice (Note 48). Equally, in 1985, many Judges were dismissed or unceremoniously retired (Note 49); with a hostile atmosphere of insecurity of tenure as above briefly discussed, it becomes not too certain that the independence of the judiciary can be ensured.

Corruption is another curse responsible for a lack of judicial independence in Nigeria. It is an open secret that corruption has tragically enveloped the whole country and the judiciary not therefore being an exception has been enmeshed in this vice.

Apparently, where the judiciary is corrupt, justice goes to the highest bidder and it becomes a question of cash and carry. Commenting on the issue of corruption in the judiciary, Oputa J.S.C. (as he then was) remarked: (Note 50)

Money they say is the root of all evil. The Bench is definitely not a place to make money. A corrupt Judge is the greatest curse to afflict on any nation. The passing away of a great advocate does not pose such public danger as the appearance of a corrupt and/or weak judge on the Bench for in the latter instance, the public interest is bound to suffer and justice...is thus depreciated and mocked and debased. It is better to have an intellectually average but honest judge than a legal genius who is a rogue. Nothing is as hateful as venal justice, justice that is auctioned, justice that goes to the highest bidder.

Amongst other notable factors that impede independence of the judiciary is the lack of independent machinery for the enforcement of its decision. Alexander Hamilton commenting on the effect of lack of self enforcement machinery for the judiciary observed: (Note 51)

The judiciary is beyond comparison, the weakest of the three departments of power... it has no influence over either the sword or the purse, no direction either of the strength or the wealth of the society; can take no active resolution whatsoever. It may truly be said to have neither force nor will but merely judgment.

Notwithstanding the above obvious handicaps of the judiciary arising from lack of independence, amongst other constraints. The Nigerian judiciary has had an impressive record for the defense of natural justice in general and fair hearing in particular. Perhaps, the list of such instance cannot possibly be given comprehensively in a limited work of this nature, however, it is hoped that a few examples would suffice.

In Mogaji v. Board of Customs and Excise (Note 52), the court held that it is a violation of the constitutional prohibition of inhuman or degrading treatment to organize a raid with the use of horse whips, guns, tear-gas, to strike or otherwise injure custodians of such goods. Equally, in Alaboh v. Boyles \& Anor (Note 53) the court held that the beating, pushing and submersion of the applicant's head in a pool of water by the first respondent were inhuman and degrading treatment. The court also declared unconstitutional, the arrest and detention of innocent 
citizens for the offence of another person in A.C.B. v. Okonkwo (Note 54) where Niki Tobi J.C.A. (as he then was) observed:

I know of no law which authorizes the police to arrest a mother for an offence committed by the son. Criminal responsibility is personal and cannot be transferred. A police officer who arrested " $A$ " for the offence committed by " $B$ " should realize that he has acted against the law. Such a police officer should in addition to liability in civil action be punished by the police authority.

In Onu Obekpa v. C.O.P. (Note 55), it was held that bail to a person accused of an offence other than a capital offence is a basic constitutional right and undoubtedly the right to release before trial is much more basic where trial is going to last more than two months for a non-capital offence. In the case, the state counsel opposed an application for bail of the accused on the ground that he had not stayed in detention up to two months as envisaged by Section 32 (1) of the 1979 Constitution to entitle him to bail.

The position of the court above was in accord with a sense of justice and the constitutional provision which presumes innocence of an accused until proved guilty (Note 56). This is because if an accused person who is detained for two months on a mere allegation is eventually pronounced innocent by the court, he would have been made to suffer in vain.

In Aiyetan v. Nifor (Note 57), the Supreme Court held that:

The principle of natural justice as enshrined in the rules of common law and section 33 (1) of the 1979 constitution is not confined to courts or tribunals establish under section 6 (5) of the 1979 constitution, but to every situation whenever a person or authority is concerned in the determination of the rights of another.

The supreme court in interpreting the provision of section 33 (1) of the 1979 constitution in relation to investigations of Constitution Investigation Committee in Adenyi v. Governing Council of Yaba Tech (Note 58) held that:

Section 33(1) of the 1979 Constitution which guarantees and has entrenched fair hearing is in strict interpretation limited to the determination of civil rights and obligations. It follows therefore that where the determination of civil rights and obligations are in issue, particularly in an investigation committee, the observance of fair hearing is not stricto sensu obligatory.

It is noteworthy to stress here that the position of the court above that section 33 (now Section 36 of the 1999 Constitution) does not apply to contractual relationship of master and servant is grossly misconceived. This is because the strict interpretation given to the provision by the court cannot be the intentions of the law-makers. When a person is employed in the public service, the person exercising the power to terminate must derive his power from law.

By any construction, the decision in respect of the determination of contract of employment comes within the contemplation of section 33(2) (Note 59). It is however, a different ball game if the contract of employment has explicitly stipulated that the employment could be terminated without notice or hearing. In that case, the employee would have been deemed to have waived his right to fair hearing with such clause in his contract of employment. But in the absence of such provision, the position of the court is final as termination of contract of employment is definitely an action which has a decisive effect on a person's right and therefore fair hearing must be observed. This is more so where the party who wants to terminate an appointment or to effect a dismissal is a public officer, there is the requirement of fair hearing in the restricted sense of natural justice.

In Sariki v. Burma (Note 60), it was held that where a statute fails to provide for natural justice, the justice of the common law supplies the omission. Thus, even in the absence of statutory provision that a person should be given a fair hearing, it is still incumbent at common law to accord an individual the right of being heard before a decision which negatively affects him is taken.

Nevertheless, in Babatunde Anisun \& Ors v. Adeleke Osayomi \& Ors (Note 61) the Court set aside the judgment of a High Court of Ijero-Ekiti for denying the Appellants a hearing before giving judgment against them in a chieftaincy dispute instituted by the Respondents.

The judgment of the Lagos High Court in the case of Chief M.K.O Abiola \& Amb. Babagana Kingibe v. The State (Note 62), presided over by Dolapo Akinsanya J. which declared the Interim National Government led by Chief Ernest Shonekan illegal, null and void is a thump up for the judiciary in defense of law. Similarly, the decision of 
the Supreme Court in INEC v. Balarabe Musa \& Others (Note 63), where the court declared null and void, the provisions of the Electoral Act 2001 which prescribed over and above the constitutional requirements for eligibility to contest an election is quite commendable of the judiciary.

Although, many are of the opinion that the judiciary has failed in its sacred duty as the last hope of the common man, from the above consideration, it would be seen that the judiciary is an indispensable factor in the defense of the observance of the principles of natural justice and the rule of law which is an integral element that makes the observance of natural justice possible in a civil administration.

\subsection{Military Administrations in Nigeria}

Since Nigeria became an independent country on the $1^{\text {st }}$ October, 1960, there has been seven Military Administrations commencing with the Military regime of General Aguiyi Ironsi, which took power from the $16^{\text {th }}$ January, 1966 and terminating with the Military regime of General Abdusalami Abubakar on $29^{\text {th }}$ May, 1999 (Note 64).

Upon assumption of office, the Military promulgated the (Suspension and Modification) Decree (Note 65), which abolished amongst other institutions, parliament and Regional legislatures. The Decree provides in section 3 that: (Note 66)

The Federal Military Government shall have power to make laws for the peace and good governance of Nigeria or any part thereof on any matter and that the Regional Military Administration can only legislate on matters in concurrent list with the prior permission of the federal Military Government.

The Decree in addition vested the executive authority of the Federal Republic of Nigeria in the Head of the Federal Military Government (Note 67) who may delegate his power to the Military Governor in the regions. Sadly enough too, the fortunes of the Nigerian judiciary under the Military was adversely affected by the combined effect of the provisions of section 1 (2) and (6) of the Decree, after providing that the constitution shall have the force of law throughout Nigeria, it went on to say that nothing in the constitution shall render any provision of a Decree void to any extent whatsoever, whilst section 6 of the Decree provided that no question as to the validity of this or any other Decree or any Edict shall be entertained by any court of law in Nigeria.

Obviously, the foregoing provisions have handcuffed the court in the exercise of its judicial powers. The response of the Nigerian courts to the above provisions of the Decree was a mixed one. For instance, in Ogunlesi and Ors $v$. A.G. Federation (Note 68) two Decrees of the Federal Military Government were challenge as ultra-vires. The Lagos state High Court held that the unlimited legislative competence of the Federal Military Government overrides the constitution.

Similarly, in Adamolekun v. The Council of University of Ibadan (Note 69), the Supreme Court while holding that it could not question as ultra-vires, the federal Military Government in making a Decree, however further held that the courts have jurisdiction to declare an Edict void, if it is inconsistent with a Decree or the constitution. Judicial courage was more pointedly exhibited against the Military Decree when in Lakanmi and Kikelomo v. A.g. Western State \& Ors, (Note 70) the court declared a Decree of the Federal Government as invalid.

It needs to be stressed that the decision in Lakanmi's case spurred the Federal Military Government to promulgate the Federal Military Government (Supremacy and Enforcement of Power) Decree (Note 71), which amongst others asserted that the event of $15^{\text {th }}$ January, 1966 was a revolution and which by implication had changed the legal order of the country. This implicitly meant that the Supremacy of the Constitution had been dethroned and replaced with that of a Decree.

Nevertheless, all the Military Administrations that have so far ruled the country have common characteristics or features which were made manifest in the promulgation of Decrees heavily decked with ouster clauses, suspension and modifications of the constitution, establishment of Military Tribunals to try classified offences amongst others. These exclusionary decrees make the principle of Natural Justice mute under the military.

\subsection{Natural Justice and Military Administrations in Nigeria}

By any definition, Military regimes and the rule of law are antithetical. While one is ruled by force, the other is by law.

However, it is pertinent to examine Military Administrations having become part of the nation's history, though via irregular means. For all intents and purposes, they could be treated as any other Administration (civil) especially for the purposes of examining the existence of the rule of law under it and by necessary extension, the quantum of natural justice available to the citizenry in a military administration. 
Military rule has much more than the civilian administration had a profound, far reaching and traumatic impact on the protection of human rights in Nigeria. Whereas, the civilian administration being a constitutional government is expected to conform with the supremacy of the constitution and all its actions made subject to judicial review, that however is not necessarily true of a military government that has the tradition of either suspending or modifying the constitution once it seizes power as what is saved or preserved in the existing constitution remains in force at the will of the federal military government and as supplement to any other decree which is subsequently issued by that body.

The State Security Detention of Persons Decree No. 2 of 1984 as amended which was promulgated by the Buhari/Idiagbon Military regime constituted a monumental minus to the observance of the principles of natural justice under that military administration. Indeed, the Decree in its section 1 (1) provided that: (Note 72)

\section{If the Chief of Staff, Supreme Headquarters is satisfied that any person who is or recently has been connected with acts prejudicial to the nation or in preparation for investigation of such acts and by reasons of which it is necessary to exercise control over, he may by order in writing direct that the person be detained in a civil prison or police station}

Section 2 of the Decree provides for a review by the Chief of Staff Supreme Headquarters of every case of detention under the Decree every three months with a view to determining whether it is necessary to continue such detention. Section 3(1) of the Decree validates all detentions of persons prior to the promulgation of the Decree, whilst section 4 (1) contains an ouster clause to the effect that no suit or proceedings shall be brought against any person for anything done or purported to be done in pursuance to the Decree. Chapter IV of the constitution which contains fundamental human rights provisions were suspended for the purpose of the Decree.

Pursuant to the provisions of this Decree, many people especially the overthrown second Republic leaders were detained for months without trial. Professor Nwabueze expressing his disapproval of the import of Decree No. 2 remarked that: (Note 73)

Although the offence of corruption for which the Decree was applied against some of the second Republic Civilian leaders which led to their detention was a notorious act, but it does not follow that all the detained leaders were guilty since they have not even been tried and therefore, it was unsafe and unjustifiable to have lumped them together for indiscriminate and indefinite incarceration without trial.

He finally opined that it is better that nine guilty persons should go free than one innocent person be wrongly punished.

Decree No. 13 (Note 74) promulgated by the Buhari/Idiagbon Administration contained an omnibus ouster clause.

No civil proceedings shall lie or be instituted in any court for or on account of any matter or thing done or purported to be done under or pursuant to any Decree or Edict and if any such proceedings are instituted before, on, or after the commencement of this Decree, the proceedings shall abate, be discharged and made void.

The above provision of the Decree is, however, quite understandable because according to Prof. Nwabueze, the aim of such provision is to ensure the comprehensiveness of the exclusionary provisions. The executive or administrative acts of the military government under this Decree were impenetrably shielded from judicial review and that all possible loopholes for the court's intervention were effectively plugged (Note 75).

Without prejudice to the above, the extent of constitutional protection available to a citizen under a military administration is far less than that available to him under a constitutional democracy. In any event, ouster clauses not only limit the operation of fundamental rights provisions, but also judicial review of administrative actions. Thus, even where the rights of the citizens are being unjustifiably trampled upon vide military legislative supremacy or executive or administrative action duly fortified by ouster clauses, the right to redress the oppressive action would be abated and in abeyance, courtesy of ouster clauses. Certainly, this scenario does not augur well for the observance of natural justice.

Exclusion of right of appeal clause in the Decree setting up military tribunals is another feature that infringes on the citizen's rights. For instance, under the Buhari/Idiagbon regime, all Decrees establishing tribunals for the trial of certain offence contained provisions to the effect that no appeal shall be made from a decision of any tribunal under the Decree (Note 76).

However, there are a few instances where military tribunals which were established by military Decree provided for right of appeal. For instance, the Recovery of Public Property (Special Military Tribunal) Amendment Decree 
(Note 77) established a special Appeal Tribunal to hear and determine appeals from decisions of the Recovery of Public Property Tribunal, Special Military Tribunal Decree 1984. The Exchange Control Anti Sabotage Decree 1984 and the Counterfeit Currencies Special Provisions Decree 1984 as amended by the Counterfeit Currencies Special Provisions (Amendment) Decree 1986. The appeal tribunal may confirm, vary or set aside the judgment on order of the tribunal or maintain and uphold the conviction and discuss the appeal or allow the appeal and set aside the conviction.

Moreover, the Decree (Note 78) creating the Robbery and Firearms Tribunals and which prescribed capital punishment for convicted offenders does not provide a right of appeal from decisions of the tribunals. Although, there must be an end to litigation but trial in Military tribunals which forecloses constitutional right of appeal is evidently a breach of fair hearing.

Military Tribunals are usually composed of only or mainly soldiers with no knowledge of law or no regard for human rights or due process of law. This ultimately occasion a breach of fair hearing.

Retroactive legislation in criminal matters is yet another feature of the military administration which unleashes constraints on the observance of natural justice. Section 33(8) of the 1979 Constitution, now section 36(8) of the 1999 Constitution (Note 79) prohibits outrightly, retroactive (Note 80) legislation in criminal matters and this provision cannot be derogated from under any circumstances. For examples, section 36 (8) of the 1999 Constitution which is impari materia with the provision of 1979 Constitution provided that:

No person shall be held to be guilty of a criminal offence on account or omission that did not at the time it took place constitute such an offence and no penalty shall be impose for any criminal offence heavier than the penalty in force at the time the offence was committed.

Sadly however, most of the Decrees with penal implications enacted by the Buhari/Idiagbon regime had retroactive effects. Undoubtedly, retroactive laws certainly infringes upon basic human rights, fundamental freedoms, the rule of law amongst other unpalatable effects. Just as the promulgation of ad hominem (Note 81) Decrees by the Military Administration infringes on the principles of natural justice. Ad hominem Decrees are usually promulgated in the course of trial to secure the conviction of an accused that is standing trial.

A good case in point is the trial of Major General Zamani Lekwot and six others in connection with the Zango Kataf disturbances. In that case, the defense counsel, Chief G.O.K. Ajayi had filed an ex parte motion at the Kaduna High Court, asking that the tribunal be restrained from continuing the trial until the issue of fundamental human rights was addressed by the Supreme Court. Former President Babangida signed Decree 55 which ousted the jurisdiction of the court in respect of anything connected with the tribunal.

Consequent upon the promulgation of the Decree, the defense counsel withdrew from the case. In the end, Lekwot and others were convicted.

Similarly, while the action challenging the annulment of the June $12^{\text {th }} 1993$ elections was going on in a Lagos High Court, three new Decrees were promulgated outing the jurisdiction of the court over the matter (Note 82).

The regime of General Sani Abacha equally denied Late Chief M.K.O. Abiola the right to be heard when it tacitly refused to appoint Justices of the Supreme Court to make up the required number of Justices to hear Late Abiola's case which he instituted to challenge the annulment of the 1993 presidential election. The Justices of the Supreme Court were not fully constituted to hear Abiola's case as most of the available Justices could not hear the case as there was a pending action instituted by them against Chief Abiola's Concord Newspaper over a libelous publication which disqualifies them on account of possible bias. Nevertheless, the regime of General Abacha deliberately refused to fill the vacancy in the Supreme Court as a device to frustrate Chief Abiola's action, which could not be heard until he died in custody in 1998 .

\section{Conclusion}

With the above consideration of the observance of the principles of natural justice under civil and military administrations, coupled with the analysis of the historical antecedent of the doctrine and several human rights declarations globally and other incidental matters amongst others, it remains to add here that the observance of the principles of natural justice is not cultured in specific or geographical bound. Evidently, the demand for its observance has not changed; neither has the effects of its violation changed too. It has continued as it has been from ages, as human nature too has remained the same.

Justice is thus rightly regarded as the "bond of society" the "cornerstone of human togetherness". It is the condition in which the individual can feel able to identify with society, feel at home with it, and accept its rulings. 


\section{Recommendations}

It is said that no problem will ever exist without being accompanied by its own solution. Thus, it becomes imperative that the already identified problems are turned over to unveil the accompanied solution.

In the area of enforcement of the law, it is essential that the principle of natural justice is given utmost attention as opposed to rigid and technical justice all in the guise of enforcing the law simplifier. Thus, even where an action is statute barred, the court should not just first be divested of its jurisdiction. It should at least consider the cause of the delay in instituting the action within time with a view to finding out the reasonableness or otherwise of such a delay.

As it affects delegation of authorities, the enabling law should state in precise and discernable manner how such discretion should be exercised and subjectively varied or modified to include how and when the conferred powers become exercisable and not when the administrator thinks fits, or in his own opinion expedient.

Without adequate and comprehensive legal devices, which may include wide and compulsory publicity of delegated legislation to enable the people for whom it is meant not only to know of its existence but the extent of powers conferred on the administrator is needful.

The ousting of the jurisdiction of the court on grounds of locus standi or ouster clauses which shut out citizens from seeking judicial remedy should be reviewed by way of abrogation wherever human rights violation is involved.

The judiciary should be cleansed so as to make it live up to its accolade of the last hope of the common man. Corrupt judicial officers should be dealt with. Effort to guarantee independence of the judiciary should be made. Such measure may include the appointment of judges by the judicial arm of government without giving such right to the executive anymore and the strict financial isolation of judicial funding.

Finally, human right bodies and institutions should be strategically located in some parts of the rural areas as a way of making free legal services available to the rural dwellers instead of their undue concentration in towns and cities.

\section{Notes}

Note 1. Oppenheim, 1., International Law, a Treatise, Vol. 1 Peace, $8^{\text {th }}$ ed., P. 91.

Note 2. Ezejiofor, G.I., Protection of Human Rights and the Law, Butterworths, London (1964) p. 3.

Note 3. Egwummuo, J. N., Modern Trends in Administrative Law, Academic Publishing Company, Enugu, $2^{\text {nd }}$ ed., (2006) p.310.

Note 4. Ibid.

Note 5. (1703) I Salk 105.

Note 6. (1797).

Note 7. (1725) 2 I.D. Raym 613.

Note 8. (1615) 11 Co. Rep. 936.

Note 9. (1832) 2 C \& Y 58.

Note 10. (1864) 16 CB 403.

Note 11. (1980) 13 M.L.R. 281.

Note 12. (1874) L.R.9 EX. $190 @ 196$.

Note 13. (1911) A.C. $179 @ 182$.

Note 14. Ume, F.E.O. The Courts and Administration of Law in Nigeria, Fourth Dimension Publishing Co. Ltd. Enugu, (1989) p.183.

Note 15. (1962) W.N.LR. 93.

Note 16. Ibid,@p.98.

Note 17. (1959) E. R. N. L. R.59.

Note 18. (1957) W.R.N.L.R. 173.

Note 19. ( 1961) W.N.L.R.. 95. 
Note 20. (1825) 3 H.L. 759.

Note 21. (1924) 1 KB 156.

Note 22. (1969) 1 Q.B.579.

Note 23. (2001) 13 NWLR (pt.685) $576 @ 581$.

Note 24. Ume, C.F.E. op. cit., p.180.

Note 25. Sagay, I. E., Recipe for Survival, being a keynote address delivered at the 2004 Nigerian Bar Association, held in Abuja from $22^{\text {nd }}-27^{\text {th }}$ August (2004) p. 1.

Note 26. CFRN, Cap C23 LFN 2004.

Note 27. Cap C23, LFN, 2004.

Note 28. (2007) 13 NWLR (pt.1049)676@681.

Note 29. (2006) 2 NWLR (pt. 963) 151.

Note 30. (2002) 7 NWLR (pt.765) 188.

Note 31. (2006) 7 NWLR (pt. 979) 245.

Note 32. (2003) 10 NWLR (pt. 829) 465.

Note 33. (2004)1 NWLR (pt. 853) 94.

Note 34. (2008)7 NWLR (pt. 1086).

Note 35. (2003) 13 NSCQR 542.

Note 36. (2001) 5 NSCQR $487 @ 491$.

Note 37. Section 4 (8) 1999 CFRN.

Note 38. Section 4 (2) Ibid.

Note 39. Section 4 (3) Ibid.

Note 40. (2002) 5 S.C.M. $1 @ 10$.

Note 41. (2002) 5 S.C.M. $1 @ 12$ - 13.

Note 42. 2000.

Note 43. (1981) 2 N.C.L.R. 459.

Note 44. Cap C41LFN, 2004.

Note 45. Cap C42LFN, 2004.

Note 46. Cap A3LFN, 2004.

Note 47. See 'The Punch News Paper of Monday April 29, 2013. Page 19.

Note 48. Osita, N.O., op. cit., p. 268.

Note 49. Ibid., p. 269.

Note 50. Fasheye, O.M., The African Guardian, Saturday November 13; (1993) p. 20.

Note 51. Quoted in Osita, N.O., op. cit., p. 273.

Note 52. (1982) 2 N.C.L.R. $552 @$ @p. $561-562$.

Note 53. (1984) 3 N.C.L.R. 830.

Note 54. (1997) 1 N.W.L.R. (pt. 18) 190.

Note 55. (1982) 2 N.C.L.R 420.

Note 56. Section 36 (5) 1999 CFRN.

Note 57. (1987) 3 N.W.L.R. (pt. 59) 48.

Note 58. (1993) 5 N.W.L.R. (pt. 50) 472.

Note 59. Now section 36(2) 1999 CFRN.

Note 60. (1962) 2 All N.L.R 62.

Note 61. (2002) 7 NWLR (Pt. 790) p. 234. 
Note 62. The African Guardian, Monday 22 November, (1993) pp. 17 - 21.

Note 63. (2003) 13 N.S.C.R. 146.

Note 64. The Nigerian Tribune, Monday 12 July, (1999) p. 6.

Note 65. No. 1 of 1966.

Note 66. Ibid.

Note 67. Section 7; Ibid.

Note 68. (1970) LD/28/69 unreported.

Note 69. (1967) S.C. 378.

Note 70. (1971) 1 U.I.L.R. 201.

Note 71. (1966).

Note 72. Decree No. 2 of 1984.

Note 73. Nwabueze, B.O., op. cit., p. 320.

Note 74. 1984.

Note 75. Nwabueze, B.O., op. cit., p. 110.

Note 76. Ibid., p. 50.

Note 77. No. 3, 1984.

Note 78. No. 5, 1984.

Note 19. Cap C23 LFN, 2004.

Note 80. Also known as retrospective laws.

Note 81. The African Guardian, Monday 22, November, p. 14.

Note 82. The African Guardian, Monday November 22, (1993) p. 21.

\section{Copyrights}

Copyright for this article is retained by the author(s), with first publication rights granted to the journal.

This is an open-access article distributed under the terms and conditions of the Creative Commons Attribution license (http://creativecommons.org/licenses/by/3.0/). 